\title{
Naturvidenskabernes kanonisering. Forskere, erkendelser eller kulturarv
}

\author{
Kristian HVidtfelt Nielsen*
}

Title: The "canonisation" of the natural sciences.

Abstract: This paper concerns recent official attempts to place science in Denmark within the context of a cultural canon. Based on differentiation between Mode 1 and 2 knowledge production, the paper points out that such attempts are highly contextualised and contingent on their different modes of application. Consequently, they entangle scientific expertise with other social skills and qualifications. Like science museums and science centres, they are a means of dealing with science in the public agora, i.e. the public sphere in which negotiations, mediations, consultations and contestations regarding science increasingly take place. Analysing the ambiguities and uncertainties associated with the recent official placing of science within an overall cultural canon for Denmark, this paper concludes that even though the agora embodies antagonistic forms of interaction, it might also lead the way to producing socially robust knowledge about science.

Keywords: Cultural canon, science, Mode 1 and 2 knowledge production, Mode 2 society, agora, science museums, science centres.

Naturvidenskab er ikke med i den officielle, danske kulturkanon, som blev sat i værk af Kulturministeriet i 2005 (Kulturministeriet 2006). Det provokerede Magisterbladets redaktør Mogens Tanggaard, der udtrykte en vis fortørnelse over, "at naturvidenskaberne og deres udøvere ikke regnes for noget, når talen kommer på kulturarv, dannelse og national identitet" (Tanggard 2005). ${ }^{1}$ Tanggaards indignation blev tilsyneladende delt af mange. Sideløbende med Kulturministeriets kanonprojekt var der nemlig en række forsøg på en selvstændig kanonisering af dansk naturvidenskab. Det er disse meget forskellige naturvi- denskabskanoner samt deres bredere betydning for offentlighedens forståelse af naturvidenskab, som jeg i denne artikel vil komme nærmere ind på.

Naturvidenskabernes danske kanonisering var ikke én bestemt persons idé, ej heller styret af et ministerkommissorium eller lignende. ${ }^{2}$ Derfor er de resulterende naturvidenskabskanoner mere forskelligartede, end det er tilfældet med de otte danske kulturkanoner inden for arkitektur, billedkunst, design og håndværk, film, litteratur, musik og scenekunst og børnekultur, alle udvalgt af specielt udpegede kanonudvalg. ${ }^{3}$ Den officielle kulturkanon rum- 
28 mer danske værker, "altså kunstværker, det ikke er til at komme uden om, hvis man vil beskrive, hvad der er karakteristisk og markant i dansk kultur" (Mathiesen m.fl. 2005: 5). Disse uomgængelige, danske kunstværker skal også illustrere, at dansk kunst og kultur er blevet til i et samspil og en vekselvirkning med europæiske og internationale strømninger.

I modsætning til kulturkanonens fokus på værker og deres (inter)nationale kontekst udviser de naturvidenskabelige kanoner, som denne artikel omhandler, stor variation, både når det gælder det faglige indhold og de kanoniske udvælgelseskriterier. Der er dog også visse lighedspunkter: Kanoniseringstiltagene bruger alle faglig ekspertise som belæg for bestemte typer af kanoniseringer, der i virkeligheden tjener ikke-faglige formål. For den officielle kulturkanons vedkommende var formålet i høj grad kultur- og kunstpolitisk (jf. Sanderhoff 2006; Andersen 2006). De naturvidenskabskanoner, som jeg beskriver, har ligeledes blandede dagsordener, som kan tilskrives deres specifikke kontekst. Vi befinder os altså langt fra et klassisk kanoniseringsideal, hvor det er den faglige viden og ekspertise, der alene dikterer rettesnoren og dens anvendelse. Jeg vil argumentere for, at vi her har med en ny (kanonisk) kanoniseringsform at gøre, der til forveksling ligner de nye former for videnproduktion, som er vokset frem i seneste par årtier. Kendetegnene er et stærkt fokus på anvendelse, transformation af etablerede faggrænser og en øget demokratisering af viden og videnproduktion. Det betyder, at produktion og evaluering af viden er fordelt på et stigende antal forskellige aktører, og det har konsekvenser for, hvordan vi indsamler, formidler og forvalter viden og kulturarv.

I det følgende vil jeg først uddybe mine betragtninger om de nye kanoniseringsformer, dernæst beskrive tre tiltag til naturvidenskabernes kanonisering og slutteligt skitsere kanoniseringens konsekvenser.

\section{KANONISERING: MODUS 1 Og 2}

Merete Sanderhoff (2006) skelner mellem to former for kanonisering: På den ene side den implicitte kanonisering, der hele tiden foregår inden for ethvert fagfelt, og som er med til at etablere faglige standarder og "best practices". På den anden side den eksplicitte kanonisering, der eksempelvis er fundet sted med den officielle, danske kulturkanon og med de nævnte tiltag til en dansk kanonisering af naturvidenskaberne. Sanderhoffs bidrag til debatten om kanonisering og dens effekt på samtidskunsten handler primært om førstnævnte form for kanonisering, selv om hun også henviser til og diskuterer den danske kulturkanon. Hun bruger Thomas Kuhns videnskabsteoretiske arbejde om de videnskabelige revolutioners historiske struktur til en sammenligning mellem den implicitte kanoniseringsproces inden for kunstverden og etableringen af "et kunsthistorisk paradigme for 'state of the arts"' (ibid: 77). Paradigmet, dvs. den implicitte, faglige kanon, har direkte konsekvenser for kunsten. Paradigmet bevirker, at den kunst, der kan kategoriseres inden for paradigmets rammer, opnår en kanonisk status, mens den kunst, der falder uden for paradigmet, afskrives som værende uinteressant og utidssvarende. Sanderhoffs artikel er et sympatisk forsøg på at gøre den gældende kanon inden for kunstverden lidt bredere og mere rummelig.

Den mere eksplicitte kanonisering foregår mestendels i det offentlige rum, hvilket betyder, at den kun dårligt kan sammenlignes med 
etablering af et videnskabeligt paradigme, der er en lukket og eksklusiv proces. Den inkluderer nemlig potentielt flere forskellige faggrupper og er samtidigt led i en offentlig debat eller samtale om kunstens eller - i mit tilfælde - naturvidenskabernes kulturelle betydning. Denne anden og mere åbne kanoniseringsproces har dermed flere lighedspunkter med mere aktuelle forsøg på at begrebsliggøre naturvidenskabernes og offentlighedens udviklingsdynamik og samspil. Her tænker jeg især på begreberne Modus 1- og 2-videnproduktion samt forestillingen om naturvidenskabernes rolle i den offentlige agora (Gibbons m.fl. 1994, Nowotny m.fl. 2001). Disse begrebers har betydning for, hvordan vi opfatter kanoniseringen af naturvidenskaberne i det offentlige rum, men også for naturvidenskabernes museologi.

Gibbons m.fl. (1994) beskriver to kanoniske måder at producere ny viden på. Den ene Modus 1 - udspringer af et klassisk videnskabsideal og traditionel videnskabsteori. Inden for Modus 1-videnproduktion eksisterer der faste, etablerede socio-kognitive forskrifter for god videnproduktion og dertilhørende evidenskriterier. Modus 1-videnproduktion er m.a.o. paradigmebaseret. Paradigmet indeholder den gældende videnproduktions normer og værdier, foruden metodiske forskrifter og de såkaldte, kuhn'ske eksemplarer, dvs. de konkrete problemformuleringer og problemløsningsstrategier, som fagfolk fra begyndelsen af deres uddannelse stifter bekendtskab med. ${ }^{4}$ Modus 1-videnproduktion giver ikke anledning til megen tvivl om en evt. kanonisering af naturvidenskaberne eller andre videnfelter. Den skal - og bør - foregå ved, at den etablerede og anerkendte ekspertise i form af fagfolk udpeger kanonen, i ental og ikke til debat. Her er der ikke plads til en bredere offentlig diskussion af kanonens indhold, endsi- ge betydning. Den får ganske enkelt mening $\mathrm{i}$

kraft af at være strengt fagrelateret, ligesom det er tilfældet med den kunstkanon, som Merete Sanderhoff (2006) omtaler.

Modsætningen til Modus 1 er Modus 2-videnproduktion. Her er videnproduktionen tæt knyttet til specifikke, anvendelsesrelaterede kontekster og ikke til disciplinære paradigmer. Modus 2-videnproduktion er derfor transdisciplinær, dvs. overskrider og omdefinerer traditionelle faggrænser, alt afhængig af hvilken anvendelseskontekst, der er på spil. Organisationsformen er mangfoldig, og der er en høj grad af resultatansvar, kvalitetskontrol og refleksivitet indbygget i Modus 2-videnproduktionen, som primært har sit udspring i naturvidenskaberne og de tekniske videnskaber, selv om visse del af humaniora også har Modus 2-lignende karakteristika. Fremkomsten af Modus 2-videnproduktion hænger nøje sammen med udbredelsen af markedsorienterede innovations- og kvalitetssikringsstrategier inden for såvel den private som den offentlige sektor. Viden bliver i stigende grad kommercialiseret som en vare på lige fod med traditionelle produkter og services. Forskning er dermed en mere målrettet, måske endda fakturarettet, proces, der ikke længere henter sin epistemiske legitimitet fra de videnskabelige paradigmer eller fra den popper'ske forbindelse mellem opdagelses- og begrundelseskonteksten (Popper 1959), men snarere søger at integrere opdagelse, udvikling og brug på baggrund af kostøkonomiske overvejelser.

Kanonisering af Modus 2-videnproduktion er ikke muligt, i hvert fald ikke i den oprindelige forstand af kanonbegrebet som rettesnor, forbillede eller eksemplar. Der skal - og bør ikke være sådanne rettesnore, for alt kan i princippet være anderledes, det afhænger helt af den pågældende problemstilling. I sin rend- 
30 yrkede form bygger Modus 2-videnproduktion altså på et udtalt ønske om at forandre sine egne mulighedsbetingelser og anvendelsesmuligheder. Derfor ønsker Modus 2-aktører ikke at kanonisere deres produkter eller metoder, dels fordi sådanne altid er - og bør være - radikalt lokaliserede og temporære, og dels fordi nytænkning og fremskridt ikke længere bliver forstået som en kumulativ bevægelse (med mulighed for langsommelige historiske revolutioner), men snarere som en pågående konkurrencesituation mellem forskellige former for viden og videnproduktion. Når videnproducenter kun relaterer sig til hinanden gennem indbyrdes konkurrenceevne og kortvarige partnerskaber, eksisterer grobunden for en egentlig kanon med en solidt funderet faglig accept ikke mere. I stedet blomstrer de mange sporadiske, lokale minikanoner, som kun har mening i kraft af deres ret begrænsede geografiske og tidslige anvendelsesområde.

Distinktionen mellem Modus 1 og 2-videnproduktion og dertilhørende kanoniseringsformer er naturligvis udtryk for en vis idealisering. Virkelighedens kanoner kan sagtens integrere blandingsformer af Modus 1- og 2-kanonisering, som det for eksempel er tilfældet med det danske kulturkanonsprojekt. Som udgangspunkt var det et rent Modus 2-kanoniseringsprojekt, lavet for at give borgere en let indgang til dansk kunst og kultur, for at styrke fællesskabet og for at "give os referencepunkter og bevidsthed om, hvad der er særligt ved danskere og ved Danmark i en verden, der bliver mere og mere globaliseret" (Mathiesen m.fl. 2006: 4-5). Trods dette demokratiske og stærkt anvendelsesorienterede startskud var selve kanonarbejdet dog trods alt overladt til udvalg bestående af personer, der alle er professionelt beskæftiget med det pågældende kulturområde, altså erfarne fagfolk. Udvalgsmedlemmerne blev valgt på baggrund af deres faglige kompetence og ikke af andre grunde hvert fald ikke eksplicit. Flere af disse eksperter havde selv en stærk tiltro til en ren Modus 1- kanoniseringsform, hvilket kom til udtryk, da Brian Mikkelsen kom for skade at koble kulturkanonen meget tæt til regeringens proklamerede kultur- og værdikamp. Mikkelsen understregede dermed kanonprojektets politiske sammenhæng, hvilket stødte en del af de indkaldte eksperter så meget, at de direkte truede med at trække sig ud af projektet (se for eksempel Sørensen og Fyhn 2006). Som gode Modus 1-folk var de tilsyneladende blevet utrygge ved den store andel af Modus 2-kanonisering. Ydermere blev det samlede billedet meget mudret af, at Kulturministeriet fra begyndelsen af pålagde kanonudvalgene visse begrænsninger i selve udvælgelsesprocessen: De skulle vælge 12 værker, som skulle opfylde de overfor nævnte betingelser (uomgængelighed, betydning for dansk kultur osv.). Selve kulturkanonen var derfor i bund og grund en højst kontingent og heterogen sammensmeltning af faglig ekspertise, politisk nationalideologi og politisk-administrative muligheder og begrænsninger - altså primært Modus 2 med et passende stænk Modus 1 for at få det hele til at glide lidt nemmere ned.

De sideløbende tiltag til en kanonisering af naturvidenskaberne er ligeledes blandingsformer, hvor både Modus 1- og 2-lignende argumenter og visioner er på spil samtidigt. Også her bliver selve spørgsmålet om, hvem der har den faglige ekspertise til hvilke former for kanonisering, formuleret og afgjort i selve anvendelseskonteksten og er ikke givet gennem disciplinære paradigmer. Det har introduceret en vis dobbelttydighed i forhold til selve arbejdet med at kanonisere naturvidenskaberne og 
ikke mindst en faglig skepsis, som man ikke finder tilsvarende i klassiske Modus 1-kanoniseringsprojekter. Inden jeg tager fat på analysen af naturvidenskabernes kanonisering, vil jeg dog først sætte Modus 1- og 2-videnproduktion ind $\mathrm{i}$ en større samfundsmæssig sammenhæng med særlig fokus på naturvidenskabernes nyere museologi.

\section{KANON, NATURVIDENSKAB OG MUSEER I AGORAEN}

Fremkomsten af Modus 2-videnproduktion skal ses som led i en større socioøkonomisk transformation, der gennemtrænger centrale dele af de vestligt orienterede samfund, herunder også museumsinstitutionerne, og kan betegnes som Modus 2-samfundet (Nowotny m.fl. 2001). Det er ikke kun i forskningens verden, at der er tegn på, at modernitetsbærende institutioner som videnskaben, nationalstaten, markedet, museet og den institutionelle separation mellem offentlige og private sfærer bryder sammen - eller rettere sagt: Der sker en øget sammenfiltring af sådanne, tidligere skarpt adskilte institutioner, og det bidrager til øget samfundsmæssig kompleksitet. Samtidig medvirker den hastige viden- og teknologiudvikling til stadigt stigende materiel vækst, men også til flere miljø- og sundhedsproblemer, dvs. udbredelse af risikomomenter. Beskrivelsen af Modus 2-samfundet kombinerer således elementer fra tilsvarende beskrivelser af henholdsvis viden- og risikosamfundet. En vigtig konsekvens af Modus 2samfundet er, at forskningsbaserede og videntunge aktører udvikler sig i nært samspil med andre typer af aktører i agoraen, se nedenfor, og dermed bliver orienteret i retning af Modus 2-videnproduktion.
I museumssammenhænge ses Modus 2-tendenserne for eksempel i nye tiltag som science centers og heterogene oplevelsescentre, der er svære at indordne under modernitetens museumsopfattelse. Museet er en mere end 250 år gammel, moderne institution, som trods store samfundsmæssige omvæltninger har været overraskende stabil (Cossons 2000): Et museum rummer samlinger, forsker i dem og formidler dem til en mere eller mindre bred offentlighed. Dets centrale omdrejningspunkt er genstande og de historier, som knytter sig til genstandene, og en stor del af museets offentlige legitimitet er netop forbundet med samlingernes historiske permanens og kulturelle betydning. Science centers udfordrer denne traditionelle opfattelse af museet på flere fronter. Først og fremmest er science centers ikke bygget op omkring en samling, men benytter sig af udskiftelige og foranderlige opstillinger (ikke udstillinger), hvis to primære formål er (be)læring og underholdning (se fx Quistgaard 2006). Science centers fordrer desuden en høj grad af interaktivitet med publikum og udfordrer dermed museets faglige selvforståelse: Udgangspunktet for det, der foregår på science centers, er ikke længere den 2 imod hvad der virker i konkrete kontekster og for en given målgruppe, dvs. publikums mere eller mindre tilfældige interesser og kompetencer. Desuden er museets krav om autencitet ikke tilstede i science centers, hvor stort set kan røres ved og udskiftes, hvis det går i stykker.

Endelig henvender science centers sig primært til børn og unge. I modsætning til det traditionelle museum, der er opstået i en oplysnings- og dannelsestradition, ser mange science centers det som deres vigtigste opgave at give de besøgende en god oplevelse. Det skal være sjovt at gå på science centers. Børnene får 
32 lidt legetid, og de voksne en tiltrængt pause, måske. Det er en måde at få flere besøgende, men der ligger også en mere uddannelsespolitisk dagsorden bag: Hvis mange børn tidligt får en god og sjov oplevelse med naturvidenskab og ingeniørkunst, vil flere måske senere hen vælge en natur- eller ingeniørvidenskabelig løbebane. I et Modus 2-samfund ses det som en positiv sidegevinst ved science centers' særlige oplevelsesøkonomi.

Som blandt andre den tidligere direktør for Science Museum i London, Sir Neil Cossons (2000), har påpeget, er denne fokusering på barnlige og umiddelbare oplevelser dog ikke kun positiv, når det gælder om at opfylde succeskriterierne. Faktisk risikerer science centers at opnå det stik modsatte af hensigten, nemlig at afskrække unge fra naturvidenskab og ingeniøruddannelserne. Den store succes, som science centers indtil nu har haft - og for en stor dels vedkommende stadig har, kan nemlig medvirke til at barnliggøre naturvidenskaberne. Når børn vokser op og bliver teenagere, vil de derfor forsøge at distancere sig mest muligt fra naturvidenskab, som er kulturelt kodet med barndom og infantil opførsel. Fremstillingen på science centers medfører, at naturvidenskab bliver noget, man vokser fra, når man dannes som voksent og selvstændigt individ. Science centers kan derfor i vid udstrækning vise sig at være en del af den problemstilling, som de fra politisk og didaktisk hold er udset til at løse.

Uanset om, science centers opfylder deres politiske målsætning eller ej, er de tegn på et vigtigt element i Modus 2-samfundet: naturvidenskabernes øgede, intime vekselvirkning med andre aktører i agoraen (Nowotny m.fl. 2001). Betegnelsen agoraen stammer oprindeligt fra den græske oldtid og var det sted, hvor bystatens borgere udvekslede varer, meninger og ideer. I relation til Modus 2-samfundet er det blevet en samlebetegnelse for alle de steder, hvor samfundsaktører er i dialog med naturvidenskaberne, det være sig inde $\mathrm{i}$ folks hoveder, i politiske forhandlinger om emner, der berører naturvidenskab, i forskningstunge virksomheder, i NGO'er, i offentlige debatter, $\mathrm{i}$ internationale samarbejdsorganer, $\mathrm{i}$ offentlige eller halvoffentlige forskningsinstitutioner osv. Eller i science centers, som udgør den del af agoraen, hvor naturvidenskabsformidlingens målgruppe bliver så bred som mulig, og hvor naturvidenskab inddrages mest muligt $i$ oplevelsesøkonomien. Science centers er derfor yderst vigtige institutioner, når det gælder vekselvirkningen mellem naturvidenskabelig forskning, den offentlige forståelse af naturvidenskab og rekrutteringen til naturvidenskabelige uddannelser, dvs. naturvidenskabernes fremtid.

På sin vis er science centers også udtryk for en rendyrket Modus 2-kanonisering af naturvidenskaberne. I modsætning til videnskabsmuseet, som bygger på en unik kombination af naturvidenskabs- og museumsfaglighed med særlige historiske traditioner, definerer science centers sig primært ud fra samtidige, anvendelsesorienterede kvalitetsmål - er publikum tilfredse? Har børnene det sjovt? - og besidder dermed en iboende instabilitet. ${ }^{5}$ (Betegnelsen videnskabsmuseer fungerer her som en samlebetegnelse for medicin-, teknologi- og videnskabsmuseer.) Science centers er, hvad de er i dag, takket være en frugtbar blanding af didaktisk opfindsomhed og politisk velvilje, men der er intet i selve institutionen science centers, der signalerer langtidsholdbarhed på samme måde som museumsinstitutionen. ${ }^{6}$ Den naturvidenskabelige viden, eller kanon om man vil, som science centers præsenterer, bliver vurderet på baggrund af forskellige for- 
mer for kost-benefit-analyser, og den repræsenterer en skønsom blanding af naturvidenskabelige institutioner, oplevelsesforetagsomhed, politisk goodwill, naturfagsdidaktik og selvfølgelig de besøgende, som har en vigtig stemme gennem publikumsanalyser. Det er der intet galt $i$, tværtimod er det en meget tidssvarende måde at kommunikere naturvidenskab på, hvis man spørger samfunds- og forskningsanalytikere som Nowotny m.fl. (2001). Det er ganske enkelt endnu en måde at forhandle om en naturvidenskabelig Modus 2-kanon i agoraen, men uden det traditionelle Modus 1-kanoniseringsprojekts opdragende og moraliserende elementer.

Det samme gør sig gældende i forhold til de tre forsøg på kanonisering af naturvidenskaberne i den danske offentlighed, som er denne artikels egentlige genstandsområde. På den ene side forestiller de alle at være forholdsvis uproblematiske naturvidenskabelige kanoner som modspil til Kulturministeriets udeladelse af naturvidenskab fra det officielle kanonprojekt. På den anden side sammenfletter de - lidt i stil med science centers - en række vidt forskellige og indbyrdes inkommensurable interesser. Endvidere virker de til at overskride traditionelle faggrænser og blande forskellige videnformer. Selv om de alle i en vis udstrækning gør brug af naturvidenskabelig viden og kompetence, er deres konsekvens ikke en klassisk, Modus 1-lignende naturvidenskabskanon, men tværtimod en øget indlejring af naturvidenskaberne i agoraen.

I det efterfølgende vil jeg beskrive de omtalte kanoniseringer af naturvidenskab, iværksat af henholdsvis Magisterbladet, tidsskriftet Biozoom, Morgenavisen Jyllands-Posten og tidsskriftet Aktuel Naturvidenskab (i fællesskab) samt forfatterne til fjerde og sidste bind af den nys udgivne Dansk Naturvidenskabs Historie.
Jeg vil også foretage sammenlignende analyser mellem disse med udgangspunkt i distinktionen mellem Modus 1- og 2-kanoniseringer. Som afslutning på artiklen diskuterer jeg betydningen af disse naturvidenskabskanoner for videnskabsmuseer og science centers.

\section{KANON NR. 1: FORSKERE}

Som direkte konsekvens af Kulturministeriets kanonprojekt opstod to kanontiltag, der havde naturvidenskaberne som genstand. Det første, som jeg har allerede omtalt, blev søsat d. 29. april 2005 i Magisterbladet der opfordrede sine læsere til at udpege "fem navne på fysikere, der har flyttet grænser videnskabeligt og erkendelsesmæssigt? Mindst en af dem skal være dansker, mindst en af dem skal være ikke-europæer, og mindst en af skal være nulevende - ellers er der frit slag" (Tanggaard 2005a). I de efterfølgende numre af bladet var der tilsvarende opfordringer til at nævne navne inden for kemi, biologi, matematik og geografi/geologi. ${ }^{7} \mathrm{Da}$ fristen var udløbet var der indkommet forslag fra i alt ni læsere til fysiklisten, fem læsere havde budt på en kemi-kanon, og fem på biologi-kanonen. Mens fire læsere havde foreslået navne til matematiklisten, havde ingen bidraget til geografi/geologi-listen (Tanggaard 2005c). Fristen til sidstnævnte kanonliste blev derfor yderligere forlænget, og så strømmede det ind med bud på mange navne, ofte suppleret med "små kompendier i geografi og geologi" (Tanggaard 2005d).

På baggrund af de mange forslag sammensatte Magisterbladet en særlig liste over de danske fysikere, kemikere, biologer, matematikere, geografer og geologer (se Appendiks 1). Listen blev præsenteret for kulturminister Brian Mikkelsen d. 23. januar 2006, dagen før 
34 lanceringen af den danske kulturkanon (Tanggaard 2006a). Reaktionen var imødekommende og forstående. Blot lagde kulturministeren vægt på, at naturvidenskab hørte ind under Videnskabsministeriets ressortområde, og derfor ville han sende sagen vedr. en selvstændig naturvidenskabskanon videre til videnskabsministerens bord. Her ligger den så vidt vides endnu (Tanggaard 2006c).

Magisterbladets forskerkanon blev også publiceret i tidsskriftet BioZoom, som er medlemsblad for Biokemisk Forening, en videnskabelig forening med over 1400 medlemmer. Her optrådte den sammen med seks andre bud på naturvidenskabskanoner, hvoraf størstedelen (fem) på de ene eller anden måde understøttede eller supplerede Magisterbladets forslag til en forskerbaseret kanon. Resultatet var altså et antal lister af forskellig længde med danske forskernavne, suppleret med mere eller mindre udførlige begrundelser, typisk med udgangspunkt i forskernes videnskabelige bedrifter. Selv der også var flere kritiske bemærkninger vedrørende til idéen om en naturvidenskabelig kanon, var Thomas Söderqvist (2006a) den eneste af bidragydere til BioZooms kanontema, der konsekvent afviste tanken om at kanonisere naturvidenskaberne. Jeg vender afslutningsvist tilbage til Söderqvists kritik, som rummer flere vedkommende aspekter, også i museologisk henseende.

Det interessante ved Magisterbladets naturvidenskabskanon i denne sammenhæng er ikke de konkrete forskere, som endte med at blive udpeget. Heller ikke, at initiativet resulterede i en heterogen liste over nulevende og afdøde forskere, selv om det kommer til at spille en vis rolle $\mathrm{i}$ min afsluttende konklusion. Det særligt interessante ved Magisterbladets kanoniseringsprojekt er, at det blev gennemført helt uden autoritative bidrag fra forskerver- den, dvs. fra etablerede paradigme-repræsentanter. Sandsynligvis har den faglige viden, som de mange læserforslag har baseret sig på, været af meget høj kvalitet. Det vidner ikke mindst de mange og lange begrundelser, "kompendierne", som Magisterbladet modtog sammen med forslagene, om. Men uanset kvaliteten er der tale om bidrag fra en blandet gruppe af personer, hvis faglige og personlige interesser i Magisterbladets kanoniseringsprojekt i sagens natur er uklare og dårligt definerede. Vi er her så langt fra en Modus 1-kanonisering, som man nok overhovedet kan komme.

Projektet opstod desuden i en tilfældig, markedsorienteret anvendelsessituation. Dets udgangspunkt var den officielle kanon, som jo selv var tiltænkt en ganske særlig kulturpolitisk rolle nu og her under den siddende regering. Magisterbladets kanonprojekt opstod som en modreaktion på naturvidenskabernes udelukkelse fra det gode kulturselskab. Mogens Tanggaard (2005d) formulerede det selv således: "Som sædvanlig - fristes man til at sige - regnes naturvidenskab ikke for 'rigtig' kultur på linje med litteratur, musik, kunst, design, film, arkitektur osv.” Dermed kan projektet ses som et forsøg fra Magisterbladets side på at sidestille "de to kulturer" (Snow 1966), altså humaniora vs. naturvidenskab, som begge er fagligt organiserede i Dansk Magisterforening. Den anvendelsesorienterede kontekst, som Magisterbladets forskerkanon udspringer af, er altså dobbelt: Dels som en enkeltpersons forsøg på at gøre noget ved en ægte ærgrelse på naturvidenskabernes vegne, dels som udtryk for fagforeningens ønske om at profilere sig som en handlekraftig og samvittighedsfuld faglig organisation for naturvidenskabelige kandidater. Magisterbladets kanon kan således opfattes som et stærkt kontekstafhængigt pro- 
dukt, hvis formål også er at fungere på (arbejds)markedet ved at markere Magisterforeningens faglige profil. Hvad angår de mere specifikke kvalitetsmål for kanonen, var de fra begyndelsen af udliciteret til læserne, og derfor underlagt en skønsom blanding af personlige og faglige ambitioner. Heller ikke, hvad angår selve indholdet af kanonen, havde Magisterbladets kanon Modus 1-træk.

\section{KANON NR. 2: ERKENDELSER}

En anden naturvidenskabskanon, som så dagens lys i kølvandet på kulturkanonen, blev iværksat af Morgenavisen Jyllands-Posten med god hjælp fra det populærvidenskabelige blad Aktuel Naturvidenskab (Appendiks 2). Avisens indblikredaktør Pierre Collignon (2006) fremhævede i sin motivation for denne kanon det urimelige i, at naturvidenskaberne ikke har fået deres egen kanon, al den stund naturvidenskab ikke alene er grundlaget for vores materielle velfærd, men også er vores eneste bolværk mod "religiøs fundamentalisme". Det er næppe en tilfældighed, at det netop var $J y l$ lands-Posten, der i den grad har følt sig udsat for "religiøs fundamentalisme" i forbindelse med Muhammed-sagen (the Cartoon Crisis), som lancerede en naturvidenskabelig kanon under henvisning til naturvidenskabernes historiske rolle som religionens modstander.

En anden interessant ting at hæfte sig ved, er Collignons afvisning af det nationale som værende et godt og tilstrækkeligt udgangspunkt for en naturvidenskabskanon. Han argumenterer for, at "vidensdeling på tværs af landegrænser er naturvidenskabernes særkende". Derfor kan en naturvidenskabelig kanon ikke begrænses til danske forskere og deres arbejde. Den må være erkendelsesorienteret med udgangspunkt i universelle teoridannelser og opdagelser. Trods det internationale udsyn har der alligevel sneget sig en national dimension ind i denne kanon. Det var nemlig udelukkende danske forskere, der blev spurgt til råds i forbindelse med udarbejdelsen af kanonen. Redaktørerne af Aktuel Naturvidenskab forestod forarbejdet og kontaktede et bredt udvalg af forskere, ca. $30 \mathrm{i}$ alt, som blev bedt om "at give deres bud på, hvad der er den største erkendelse inden for dels deres eget fagområde og dels naturvidenskaben generelt" (Kjær og Dahlgaard 2006a: 4). Fra de mange input valgte redaktørerne de 10 vigtigste og bad 10 udvalgte forskere om at uddybe hver en af erkendelserne for bladets læsere. Erkendelserne samt dertilhørende begrundelser blev offentliggjort i et særligt temanummer af $A k t u e l ~ N a$ turvidenskab samt i Jyllands-Posten's søndagsudgave. ${ }^{8}$

Det fælles udgangspunkt for denne kanon var altså erkendelser, dvs. naturvidenskabernes kognitive og metodiske indhold frem for personer, opdagelser eller opfindelser. Men "erkendelsesprojektet”, som redaktørerne Carsten R. Kjær og Jørgen Dahlgaard (2006a) kaldte det, blev præsenteret vidt forskelligt $\mathrm{i}$ henholdsvis Aktuel Naturvidenskab og Jyllands-Posten. Førstnævnte fremhævede, at listen ikke var "den ultimative naturvidenskabs-kanon", snarere et "oplæg til refleksion og diskussion i den naturvidenskabelige verden" (ibid: 5). Senere måtte de to redaktører dog selv med en vis jysk underdrivelse erkende, at projektet ikke afstedkom "en sand syndflod af reaktioner i form af læserbreve" (Kjær og Dahlgaard 2006b). De undrede sig over, "at der ikke er nogen, der har følt sig kaldet til at skrive et egentligt debatindlæg til bladet med kommentarer eller kritik af naturvidenskabs-kanonen", og konkluderede, at "naturvidenskabs- 
36 folk ikke har for vane at debattere deres hjertesager i offentlige fora." Det er et paradoks, at mens naturvidenskab tilsyneladende bevæger sig ind i agoraen, sværger mange naturvidenskabsfolk stadig til en traditionel populariseringsopfattelse, ifølge hvilken man kun udtaler sig om egen forskning og forsknings-område og ikke debatterer naturvidenskab og samfundsrelaterede problemstillinger som for eksempel denne kanon.

Jyllands-Posten var ikke så beskedne som Aktuel Naturvidenskab på kanonens vegne. Avisen præsenterede kanonen under den meget lidt ydmyge overskrift "Menneskehedens 10 største erkendelser" (Collignon 2006). ${ }^{9}$ Udover at fungere som et opgør med religiøs fundamentalisme var kanonen - i Jyllands-Postens udlægning - også et godt eksempel på, at "når vi først bevæger os ind i det oplyste univers af sammenhængende logik og observationer, der afprøver teorierne, kan vi sætte pris på, at al viden ikke er lige vigtig”. Det er påfaldende, at Jyllands-Postens kanonfremstilling sidestiller naturvidenskab med logisk rationalitet og en Popper-light udgave af falsifikationisme, mens Aktuel Naturvidenskab fremhæver den kollektive konsensus mellem forskerne som det vigtigste grundlag for kanonens gyldighed.

Trods skuffelsen fra de to Aktuel Naturvidenskabs-redaktørers side over, at deres erkendelsesprojekt ikke bevirkede mere faglig og offentlig debat, er projektet dog i sig selv - ligesom de øvrige kanoniseringsbidrag omtalt her - et tegn på, at naturvidenskaberne i dag er del af en offentlig agora. Først og fremmest udgør kanonen endnu et eksempel på en Modus 2-kanonisering af naturvidenskaberne, og dét måske i en mere åbenlys grad, end det var tilfældet med Magisterbladets kanonprojekt. Idéen til erkendelseskanonen kom fra Jyllands-
Postens redaktionslokaler og var dermed i bund og grund et kommercielt projekt, der indgik $\mathrm{i}$ den samlede markedsføringsstrategi for Jyllands-Postens forskningsformidling. Lanceringen af kanonen blev af Jyllands-Posten nøje tilrettelagt med Galathea 3-ekspeditionens afsejling $\mathrm{i}$ august måned, og kanonen fungerede dermed som et velanbragt startskud til ekspeditionen, der også udspringer af en idé fostret i Jyllands-Postens redaktion. ${ }^{10}$ Ydermere blev kanonen i Aktuel Naturvidenskabs regi også lidt uventet til et pædagogisk projekt, idet mange gymnasier bestilte klassesæt af temanummeret og inddrog erkendelseskanonen i undervisningen.

Erkendelseskanonen blev altså konciperet på baggrund af markedsovervejelser og inddrog derefter fagfolkenes ekspertise som led i den kommercielle strategi. Til udvælgelsen af de pågældende ti erkendelser blev den faglige viden kombineret med henholdsvis Jyllands-Postens og Aktuel Naturvidenskabs mere pragmatiske overvejelser af, hvad der konstituerer naturvidenskab og naturvidenskabelig erkendelse. Ud over det rent kommercielle formål blev kanonen selvfølgelig også båret af andre overvejelser som for eksempel ønsket om at stimulere en faglig debat på tværs af faggrænser og - i stil med Magisterbladets kanon - at problematisere den officielle kulturkanons udeladelse af naturvidenskaberne. Endelig var kanonen tænkt som et modsvar til de "religiøse fundamentalister", der havde angrebet $J y l$ lands-Posten under Muhammed-sagen. Muhammed-sagen fik jo som bekendt den følgevirkning for avisen, at Galathea 3-ekspeditionens rute og dermed Jyllands-Postens formidlingsplaner måtte lægges om, da det blev anset for at være for farligt at sejle gennem bla. Suez-kanalen og Det Røde Hav i et dansk flådefartøj under Jyllands-Postens banner. 
KANON NR. 3: KULTURARV

Den tredje og sidste naturvidenskabskanon, jeg vil fremhæve, er af en noget anden slags end de to foregående. ${ }^{11}$ Frem for internationale forskere eller universelle erkendelser bygger den nemlig på naturvidenskabernes danske kultur- og institutionshistorie, forhold som traditionelt set er blevet opfattet som værende eksterne i forhold til naturvidenskaberne. Det drejer sig om firebindsværket Dansk Naturvidenskabs Historie (Kragh m.fl. 2005-6). Værket er dog ikke i sig selv blevet til som et kanoniseringsprojekt, men derimod som videnskabshistorisk forsknings- og formidlingsarbejde. Men i forbindelse med publiceringen af de to sidste bind af værket skrev to af værkets fire redaktører en avisartikel, hvori de lancerede hele værket som "1000 års dansk naturvidenskabskanon" (Nielsen og Nielsen 2006).

Artiklen blev indledt med endnu en sørgesang over naturvidenskabernes fravær i den officielle kulturkanon. Det er en almen indgangsbøn i alle de fremstillinger, jeg her diskuterer. Men i modsætning til de tidligere kanoniseringsforsøg, som alle betragtede forholdet mellem naturvidenskab og kultur som ensidigt - naturvidenskab har haft en afgørende betydning for den vestlig-moderne kultur og ikke omvendt - forsøgte denne artikel indledningsvist at gøre forholdet mellem naturvidenskab og kultur mere interaktivt og ligestillet. For artiklens forfattere handlede spørgsmålet om naturvidenskabernes kanonisering ikke så meget om, på hvilken måde naturvidenskaberne har bidraget til kulturen, men snarere om, hvordan kultur kan forstås en integreret medspiller i naturvidenskabernes udvikling og omvendt. At se naturvidenskab og kultur i en tæt vekselvirkning med hinanden ligger for så vidt tæt op ad en Modus 2-beskri- velse af forholdet mellem videnproduktion og samfund. Så selv om denne måde at begrebsliggøre problemstillingen på ikke var en udtalt del af Nielsen og Nielsens fremstilling, byggede grundopfattelsen på en Modus 2-tankegang.

Dette kanoniseringsforsøg fremhævede, at det ikke alene er svært at kanonisere naturvidenskaberne på basis af dansk-national kultur. Det er også problematisk at skulle kanonisere enkeltstående forskere, da det er den aktuelle naturvidenskabelige viden om natur, som er det egentlige værk i naturvidenskaberne. Trods forbeholdene endte forfatterne alligevel ud med at etablere en egentlig kanon. Dette lidt uafklarede forhold til selve kanonbegrebet gjorde, at selve den naturvidenskabskanon, der blev præsenteret i artiklen, også var noget uklar: Kanoniseret blev den berømte danske atomfysiker Niels Bohr og den knap så kendte seismolog Inge Lehmann på baggrund af korte beskrivelse af deres faglige netværk, deres institutionelle tilhørsforhold i Danmark og i udlandet samt den viden, som de i samarbejde med mange andre forskere har arbejdet med at producere. ${ }^{12}$ Der blev argumenteret for, at en naturvidenskabskanon skulle rumme dels den naturvidenskabelige viden, dels denne videns kulturelle indlejring og betydning. En sådan naturvidenskabskanon med en særlig dansk accent er altså hele værket Dansk Naturvidenskabs Historie.

Lidt ligesom det var tilfældet med JyllandsPostens kanon, der var timet til lanceringen af medievirksomhedens Galathea 3-initiativ, kom denne kanon samtidigt med publiceringen af de sidste to bind af det omtalte bogværk. Det er derfor ikke svært at se kanonen som led i forfatternes egen pr-strategi i forbindelse med bogudgivelsen. På Medicinsk Museions blog undrede Thomas Söderqvist sig da også over, at Nielsen og Nielsen både kunne være afvisende over for kanontanken og samtidigt advokere for 
38 en dansk naturvidenskabskanon. Han konkluderede:

Nielsen \& Nielsen er ved at udgive fjerde og sidste bind af Dansk Naturvidenskabs Historie, som udkommer 11. maj. I deres akademiske kollegaers øjne vil de selvfølgelig gerne fremstå som gode videnskabshistorikere ved at afvise myten om videnskabelige kanoner. Men samtidigt vil de jo gerne også gøre god reklame for deres bog om dansk naturvidenskabshistorie. Og det er god latin blandt naturvidenskabsformidlere at kanontænkning er opskriften på en kioskbasker. Se bare på den danske videnskabsjournalist Tor Nørretranders, som har gjort kanonisering af bla. Bohr og Einstein til sit levebrød.

Nielsen \& Nielsen er med andre ord fanget i et klassisk akademisk dilemma. På den ene side vil man ugerne fremstå som naiv i sine akademiske kollegaers ('peers') øjne. På den anden side vil man jo gerne blive læst og anerkendt i en større offentlighed. Det er et dilemma, som vi allesammen er mere eller mindre fanget i. (Söderqvist 2006)

Også denne tredje naturvidenskabskanon er altså dels indlejret $\mathrm{i}$ en form for kommerciel tankegang, dels en integreret del af den offentlige diskussion om naturvidenskabernes egenart og kulturelle betydning. Ydermere er den tvetydig, idet den selv fremhæver sin forankring i solidt videnskabshistorisk forskningsarbejde, men tydeligvis også har mere debatterende og formidlingsmæssige ambitioner. Derfor bør også denne kanonisering af naturvidenskaberne forstås som Modus 2-kanonisering og ydermere som et godt eksempel på, hvorledes ikke bare naturvidenskaberne selv, men også deres kulturhistoriske dimensioner er til forhandling i agoraen.

En yderligere ting, der er værd at bemærke ved dette kanoniseringsforsøg, er, at interessen for at forstå naturvidenskaberne som integre- ret del af kultur og historie også understreger naturvidenskabernes materielle kulturarv noget som er af afgørende betydning for videnskabsmuseer og for forholdet mellem videnskabsmuseer og science centers. Hvis man udelukkende ser naturvidenskab som værende individ- eller idébaseret, som det er antydet i to første naturvidenskabskanoner, ligger faren for en ren idealisering eller "kognitivering" af naturvidenskaberne snublende nær. Enten bliver forskere forstået som metodisk-rationelle og nærmest umenneskelige entiteter, der bedriver forskning og producerer viden på universel-automatisk vis. Eller også ser man naturvidenskaberne som bestående af kognitive paradigmer, der hver især er funderet på logik og metode. Det er ofte den forståelse af naturvidenskaberne, som man ser præsenteret på science centers.

Omvendt vil en beskrivelse af naturvidenskaberne, der inddrager naturvidenskab i en historisk og materiel sammenhæng, åbne op for andre forståelsesmuligheder. Her kan elementer som teknologisk udvikling, samfundsmæssig kontekst, personligt begær og splittelse, institutionelle interesser, aktuelle markedsvilkår, mediebilledet mm. - kort sagt alt det, der indgår i en Modus 2-forståelse af naturvidenskaberne - få lov til at spille en rolle. Det sidstnævnte kanoniseringsforsøg er altså ikke bare Modus 2-præget i sig selv, men ligger op til en Modus 2-lignende forståelse af hele videnskabshistorien. Det er måske værd at tage med $\mathrm{i}$ betragtning, når fremtidens videnskabsmuseer skal udformes i skarp konkurrence med science centers og andre formidlingstiltag.

\section{ET KLASSISK DILEMMA}

De nævnte kanoniseringstiltag etablerer alle 
midlertidige, dobbelttydige og ret komplicerede kommunikationsforhold mellem naturvidenskaberne og andre samfundsaktører. Kommunikationen fungerer ikke som den klassiske populariseringsmodel, hvor naturvidenskaberne selv formidler autoritativ viden til en passiv offentlighed. I tråd med den ovennævnte beskrivelse af Modus 2-samfundet, hvor naturvidenskaberne nu er kommet til forhandling i agoraen og samtidigt er i færd med at udvikle sig til ren Modus 2-videnproduktion, kombinerer de nævnte kanoniseringstiltag naturvidenskab med medier, faglige organisationer, akademiske interesser, personlige interesser og andre agora-elementer. Ligesom andre kanoner formuleret og debatteret i et åbent, offentligt rum udgør de dermed selv et element i agoraen, hvor forskellige former for interaktivitet mellem naturvidenskab og offentligheden etableres, sættes til skue og derfor kan debatteres. På denne måde har de mange lighedspunkter med videnskabsmuseer og science centers.

Et afgørende spørgsmål er selvfølgelig hvilket naturvidenskabssyn og hvilke typer af interaktivitet, der rent faktisk kommer i spil med de nævnte kanoner og i forbindelse med videnskabsmuseer og science centers?

De tre kanoniseringstiltag, som jeg her har omtalt, bringer meget forskellige videnskabsopfattelser på spil i agoraen. I Magisterbladets kanon er det enkeltforskere, der er drivkraften bag den videnskabelige videnproduktion. Det svarer til heltedyrkelse af videnskabsfolks personlige geni og levner ikke meget plads for den mere demokratiske videnskabsopfattelse, som er indeholdt i Modus 2-tænkningen. Det samme gør sig for så vidt gældende for $J y l$ lands-Postens og Aktuel Naturvidenskabs kanon. Trods Aktuel Naturvidenskabs påpegning af videnskabskollektivet som grundlaget for videnskabelige viden understreger denne kanon, at naturvidenskab handler om (ren) erkendelse og ikke så meget andet. Alt det andet, som naturvidenskab også er og har betydning for, var derimod på spil i den tredje naturvidenskabskanon, hvor det i højere grad var naturvidenskabernes kulturhistorie, der var i højsædet. Mens de to første naturvidenskabskanoner - trods det, at de selv er meget Modus 2-prægede - trækker på et Modus 1ideal for den naturvidenskabelige videnproduktion, ligger den tredje tættere på en Modus 2-forståelse af den naturvidenskabelige udviklingsdynamik.

Men kan vi overhovedet bruge naturvidenskabskanoner til noget i et Modus 2-samfund, hvor selve den videnskabelige kerne og mange andre modernitetsinstitutioner er under hastig forandring? Thomas Söderqvist har argumenteret for, at kanoner er med til at forfladige forståelsen af naturvidenskabernes historiske og aktuelle kompleksitet:

Mine to indvendinger imod kanontænkningen er altså, at den inddrager naturvidenskab, teknologi og medicin $\mathrm{i}$ et nationalistisk projekt og at den reducerer kompleksiteten indenfor videnskabs-, teknologi- og medicinhistorien. Den bidrager godt nok til at gøre den historiske udvikling mere hjemmevant og letforståelig. Men det er samtidigt en historieforståelse, som gør os mere nationalt indskrænkede og dummere end nødvendigt er. Hvis vi, som det tit siges, lever i et komplekst, globalt videnssamfund, synes jeg, at vi burde kunne kapere lidt mere avancerede former for forstålse af hvordan naturvidenskab, teknologi og medicin udvikles. Kanoner er for dem, som ikke tør se globaliseringen i øjnene, og som ikke gider at forholde sig til historiens mangfoldighed og kompleksitet. Hvis vi, som det tit siges, lever i et komplekst, globalt videnssamfund, synes jeg, at vi burde kunne kapere lidt mere avancerede former for forståelse af hvordan 
40 naturvidenskab, teknologi og medicin udvikles. (Söderqvist 2006a)

Selv om jeg mener, at de tre naturvidenskabskanoner udgør interessante studier i Modus 2kanoniseringsforsøg, vil jeg også bifalde Söderqvists kanonkritik. Man kan endvidere pege på, at den udmærket afspejler de ovenfor refererede kritikpunkter i forhold til science centers (Cossons 2001). Som science centers giver kanoner et ahistorisk og endimensionelt billede af naturvidenskaberne og den kultur, de er en del af. Dermed risikerer man, at naturvidenskaberne reduceres til børneoplevelser i den offentlige forståelse. Jeg tror, at mange, heriblandt Söderqvist og Cossons, ville kunne skrive under på, at det blandt andet er videnskabsmuseers rolle at modvirke eller hvert fald balancere sådanne tendenser.

Videnskabsmuseer er i dag fanget $\mathrm{i}$ et "klassisk dilemma" mellem Modus 1 og 2. På den ene side bygger denne institution på et mere eller mindre udtalt ønske om at etablere tovejs, kommunikative relationer med en bred offentlighed om naturvidenskaberne og deres samfundsmæssige og kulturelle relationer. På den anden side er de ofte fast forankret i en Modus 1-tænkning, hvor det primært er de naturvidenskabelige paradigmer, der er i centrum for indsamling og formidling. Også selv om mange videnskabsmuseer nu ser sig selv som rene Modus 2-institutioner (Macdonald 1998), bygger de stadig på en Modus 1-videnskabsforståelse, altså en forholdsvis ensidig ekspertise- og kompetenceforståelse, hvor det kun er videnskabelige aktører, der har patent på viden. Hvis videnskabsmuseer - og måske også science centers og endda nye naturvidenskabskanoner - vil bidrage konstruktivt til den nye agora, kan det ofte benyttede begreb om interaktivitet med fordel udvides til ikke kun at dække over en teknologisk-medieret vekselvirkning med enkeltpersoner i selve udstillingsrummet (Barry 1998). Nye former for interaktivitet, der både bygger på, men også fremhæver naturvidenskabernes og samfundets øgede sammenfiltring og tværgående engagement er påkrævede; nye måder at omskabe museer og museumslignende institutioner i samspil med tilsvarende transformationsprocesser i Modus 2-samfundet (Söderqvist 2004). Det bliver opgaven for videnskabsmuseer og science centers fremover.

Artiklen er baseret på et foredrag afholdt i forbindelse med seminaret "Kanonisering af kunst og kulturarv", d. 9. oktober 2006, arrangeret af Center for Museologi, Aarhus Universitet.

\section{ApPENDIKS 1: MAgISTERBLADETS KANONLISTE}

Danske naturvidenskabsfolk, der kan indgå i en naturvidenskabernes kanon:

Fysik

Hans Christian Ørsted*

Holger Bech Nielsen

Niels Bohr*

Tycho Brahe*

Lene Hau

Ole Rømer*

Otto Hahn*

\section{Kemi}

Ebba Lund*

Niels Bjerrum*

Johannes Nicolaus Brøndsted*

Søren Peer Lauritz Sørensen*

Jens Christian Skou

Klaus Bechgaard

Poul la Cour* 
Matematik

Børge Jessen*

Jens Carstensen

Julius Petersen*

Agner Krarup Erlang*

J. L. W. V. Jensen*

Harald Bohr*

Vagn Lundsgaard Hansen

Ole E. Barndorff-Nielsen

\section{Biologi}

Wilhelm Ludvig Johannsen*

Niels Kaj Jerne*

Reinhard Møbjerg Kristensen

Johannes Fibiger*

Henrik Dam*

August Krogh*

Peter Wilhelm Lund*

Øjvind Winge*

Eugenius Warming*

Joakim Frederik Schouw*

\section{Geografi}

Carsten Niebuhr*

Gudmaund Hatt*

Johannes Humlum*

Martin Vahl*

Malthe Conrad Bruun*

Axel Schou*

Vitus Bering*

Jens Munk*

\section{Geologi}

Niels Steensen (Nicolaus Steno)*

Willi Dansgaard

Johannes Iversen*

Inge Lehmann*

* markerer afdøde videnskabsfolk.
ApPendiks 2: JyLLANDS-Postens og AKTUEL NATURVIDENSKABS kanon

De ti vigtigste, naturvidenskabelige erkendelser (ikke rangordnet):

1. Naturen kan forklares uden myter

2. Newtons love

3. Evolutionslæren

4. Termodynamikken

5. Verden består af atomer

6. Relativitetsteorien

7. Økologien

8. Kvantemekanikken

9. Pladetektonikken

10. DNA's struktur

1. Magisterbladet er medlemsblad for fagforeningen Dansk Magisterforening, der organiserer 36.000 kandidater og studerende inden for humaniora, naturvidenskab, samfundsfag og sundhedsvidenskab.

2. Idéen til den danske kulturkanon kom oprindeligt fra én person, nemlig billedhugger Hein Heinsen, jf. Heinsens eget oplæg på seminaret Kanonisering af kunst og kulturarv, d. 9. oktober 2006, arrangeret af Center for Museologi, Aarhus Universitet.

3. Børnekulturkanonen var ikke en del af kanonprojektet fra starten af, men blev til undervejs på udvalgsformændenes foranledning.

4. I postskriftet til andenudgaven af The Structure of Scientific Revolutions fremhæver Kuhn (1970) netop eksemplarer som særligt centrale for en forståelse af paradigmebegrebet.

5. Den skarpe adskillelse mellem videnskabsmuseet og science centers er problematisk af flere grunde. Den tjener her primært det formål at styrke billedet af science centers som et eksempel på na- 
turvidenskabernes rolle i agoraen. Meget af den samme argumentation ville uden tvivl kunne gennemføres for de fleste videnskabsmuseer, hvis man som præmis tillod en mere nuanceret museumsopfattelse (Vergo 1989, Silverstone 1992).

6. Den tidligere forsknings- og udviklingsdirektør for Amsterdams berømte, men også berygtede newMetropolis, James Bradburne (1998), har argumenteret for, at science centers vil vise sig ikke at være bæredygtigt pga. svigtende midler, mangel på inspiration og grundlæggende konflikter mellem de mange forskellige interesserenter (besøgende, forskere, politikere, museumsfolk m.fl.). newMetropolis, nu NEMO, er Amsterdams store og flotte science center og designet af Renzo Piano. Det løb kort tid efter åbningen ind i alvorlige økonomiske problemer og måtte gennem store omstruktureringer. Retfærdigvis bør det også nævnes, at Per-Edvin Persson (2000) fra Finnish Science Center senere har imødegået Bradburnes kritik. Så nu vil fremtiden vise, om science centers-konceptet kan bære i det lange løb.

7. Geografi/geologi var - lidt ligesom børnekulturen i den officielle kulturkanon, men uden sammenligning i øvrigt - ikke med i Magisterbladets kanonprojekt fra starten af. Fagene blev senere inkluderet på opfordring fra læserne (Tanggaard 2005b).

8. Aktuel Naturvidenskabs temanummer er tilgængelig på http://www.aktuelnat.au.dk/Indhold/06_3.htm. Jyllands-Posten bragte de 10 erkendelser over femfulde sider i søndagsudgaven d. 6. august 2006 .

9. Aktuel Naturvidenskab brugte den mere afgrænsede overskrift, "De største naturvidenskabelige erkendelser" (Kjær og Dahlgaard 2006a).

10. Galathea 3-ekspeditionen (august 2006 - april 2007) kombinerer forskning med kommerciel formidling på mange medieplatforme. Se for eksempel Jyllands-Postens hjemmeside om ekspeditionen, http://www.galathea.nu/, som er et godt eksempel på den aktuelle kommercialisering af forskningsformidling.

11. Den adskiller sig også derved, at denne artikels forfatter har været med til at beskrive den i en avisartikel (Nielsen og Nielsen 2006).

12. Niels Bohrs arbejde behøver ingen yderlige præsentation, men det er måske nok værd at bemærke, at Inge Lehmann er bedst kendt for sin hypotese om jordens indre kerne, fremsat i 1936 og endeligt konfirmeret/alment accepteret i begyndelsen af 1960'erne.

\section{LITTERATUR}

Andersen, Gregers: "Kulturkanonen er poetokratiets sejr". Politiken. 4. november 2006.

Barry, Andrew: "On interactivity: consumers, citizens and culture" i S. Macdonald (ed.), The Politics of Display. Museums, Science, Culture. Routledge: London 1998: 98-117.

Bradburne, James M.: "Dinosaurs and white elephants: the science center in the twenty-first century". Public Understanding of Science. Årg. 7 , 1999: 237-253.

Collignon, Pierre: "Menneskehedens 10 største erkendelser". Morgenavisen Jyllands-Posten. 6. august 2006.

Gibbons, Michael, Camille Limoges, Helga Nowotny, Simon Schwartzman, Peter Scott and Martin Trow: The new production of knowledge. The $d y$ namics of science and research in comtemporary societies. Sage: London 1994.

Kjær, Carsten R. og Jøregen Dahlgaard: "De største naturvidenskabelige erkendelser". Aktuel Naturvidenskab. Nr. 3, 2006: 4-5.

Kjær, Carsten R. og Jørgen Dahlgaard: "Erkendelser". Aktuel Naturvidenskab. Nr. 5, 2006: 33.

Kragh, Helge, Peter C. Kjærgaard, Henry Nielsen og Kristian Hvidtfelt Nielsen (red.): Dansk Naturvidenskabs Historie. 4 bd. Aarhus Universitetsfor- 
lag: Århus 2005-6..

Kuhn, Thomas S.: The Structure of Scientific Revolutions. 2. udgave. University of Chicago Press: Chicago 1970.

Kulturministeriet: Kulturkanon. Politikens Forlag: København 2006. Se også kulturkanonens hjemmeside, tilgængelig på: http://www.kulturkanon.kum.dk (hentet d. 9.11.2006).

Macdonald, Sharon: "Supermarket science? Consumers and 'the public understanding of science" i S. Macdonald (ed.), The Politics of Display. Museums, Science, Culture. Routledge: London 1998: 118-138.

Mathiesen, Dorthe Skaaning, Susanne Weihe Dahl, Christine Mehlsen og Henrik Reinberg Simonsen: "En let indgang til dansk kulturarv". Kulturkontakten. Særnummer, januar 2006: 4-5.

Nielsen, Kristian Hvidtfelt og Henry Nielsen: "Kulturel natur". Weekendavisen. 5. maj 2006.

Nowotny, Helga, Peter Scott and Michael Gibbons: Re-Thinking Science. Knowledge and the Public in an Age of Uncertainty. Polity: London 2001.

Persson, Per-Edvin: "Science centers are thriving and going strong!" Public Understanding of Science. Årg. 9, 2000: 449-460.

Popper, Karl: The Logic of Scientific Discovery. Hutchinson: London 1959.

Quistgaard, Nana: "Oplevelsen og udbyttet af skolebesøg på teknik- og naturvidenskabscenter". MONA. Nr. 1, 2006: 23-40. Tilgængelig på: http://isis.ku.dk/kurser/blob.aspx?feltid=138954 (hentet d. 19.1. 2007).

Tanggaard, Mogens: "Det akademiske kvarter - Fysikkens kanon". Magisterbladet. Nr. 8, 29. april 2005a. Tilgængelig på http://www.dm.dk/sw45233.asp (hentet d. 9.11.2006).

Tanggaard, Mogens: "Biologiens kanon". Magisterbladet. Nr. 11, 17. juni 2005b. Tilgængelig på http://www.dm.dk/sw48383.asp (hentet d. 30.11.2006).
Tanggaard, Mogens: "Det akademiske kvarter - Naturvidenskab og kulturarv". Magisterbladet. Nr. 13, 26. august 2005 c. Tilgængelig på http://www.dm.dk/sw51229.asp (hentet d. 30.11.2006).

Tanggaard, Mogens: "Det akademiske kvarter - Geografiens og geologiens kanon". Magisterbladet. Nr. 15, 25. september 2005c. Tilgængelig på http://www.dm.dk/sw53623.asp (hentet d. 30.11.2006).

Tanggaard, Mogens: "Naturvidenskabernes kanon". BioZoom. Nr. 1, 2006a. Tilgængelig på: http://www.biokemi.org/biozoom/2006_1/bz_0 106b.htm (hentet 30.11.2006).

Tanggaard, Mogens: Personlig samtale, d. 8. oktober 2006b.

Sanderhoff, Merete: "Dette er ikke en kanon. Om kanonisering og dens effekt på samtidskunsten". Nordisk Museologi. Nr. 1, 2006: 74-88.

Silverstone, Roger: "The medium is the museum: on objects and logics in time and space" i: J. Durant (ed.), Museums and the public understanding of science. Science Museum: London 1992: 34-42.

Snow, C.P.: De to kulturer. Oversat fra engelsk af Ane Munk-Madsen. Vinten: København 1966.

Söderqvist, Thomas: "Bliver vi klogere af danske naturvidenskabs-, teknologi- og medicinkanoner?". BioZoom. Nr. 1, 2006a. Tilgængelig på: http://www.biokemi.org/biozoom/2006_1/bz_0 106g.htm (hentet 30.11.2006).

Söderqvist, Thomas: "Et klassisk akademisk dilemma”. Biomedicine on Display. 6. maj 2006b. Tilgængelig på: http://www.corporeality.net/museion/?p=389 (hentet 1.12.2006).

Söderqvist, Thomas. "Biomedicinen og det moderne museums endeligt" i: H.D. Christensen, R. Gade og M.V. Hansen (red.): Museernes historie og teori. Museologisk Skriftserie. København: Institut for Kunst- og Kulturvidenskab, Københavns Universitet 2004: 75-88.

Sørensen, Rasmus Bo og Mikkel Fyhn: "Kulturmi- 
Kristian HVidtfelt Nielsen

44

nister skaber ny spild om kulturkanon". Information. 11. marts 2006.

Vergo, Peter (ed.): The new museology. Reaktion

Books: London 1989.

*Kristian Hvidtfelt Nielsen, post.doc. at the Steno Department of Studies of Science and Science Education, University of Aarhus.

Address: Steno Department, Ny Munkegade, DK-8000 Aarhus C, Denmark.

E-mail:khn@si.au.dk 